\title{
High School Teachers' Perceptions and Implementations of Group Work in English Speaking Classes
}

\section{Do Minh Hung}

Dong Thap University, Vietnam, dmhung@dthu.edu.vn

\section{Le Thi Tuyet Mai}

Dong Thap Sports, Aptitude School, Vietnam, maim1616021@gstudent.ctu.edu.vn

Pair/group work activities are now common in classroom and it is one of the prominent features of the learner-centred approach. This study aimed to investigate (1) teachers' perceptions toward group work and (2) their group work implementations in EFL speaking classes. The data were collected via a questionnaire from 105 high school English teachers within Dong Thap province (one of the remote provinces in the Mekong Delta, South of Vietnam) and videorecordings taught by 4 teachers who had answered the questionnaire and agreed to permit the researchers to record their instructions at 4 different high schools in the province, where they were working full-time. The obtained results showed that most teachers highly appreciated the significance of group work in speaking classes. They generally understood clearly its benefits, possible problems and teacher roles in supporting groups for success and enjoyment. However, for greater effectiveness in group implementation, some suggestions are given.

Keywords: teacher perception, group work, EFL speaking class, high school

\section{INTRODUCTION}

Today's teachers generally recognize that group work among learners of most subjects or learning courses is obviously one of the prominent features of learner-centred classroom, especially in communicative language ones for it is supposed to provide learners of all abilities and learning styles an equal opportunity to work, express themselves, speak out their minds and learn from others in one way or another. In this vein, if administered properly, group work in EFL speaking classes is highly promising to be a freely available tool for teachers to help learners not only practice speaking English communicatively but also improve the ability to work with others in collaboration to complete common goals. Having been trained in group work at some points during their college training programs and in-service time after graduation from

Citation: Hung, D. M., \& Mai, L. T. T. (2020). High School Teachers' Perceptions and Implementations of Group Work in English Speaking Classes. International Journal of Instruction, 13(2), 445-462. https://doi.org/10.29333/iji.2020.13231a 
college/university, EFL teachers in general and at high schools in particular throughout Vietnam are definitely now more or less exploring group work in their classes.

Likewise, high school teachers of English in Dong Thap province (one of the remote provinces in the Mekong Delta of Vietnam) are widely implementing group/pair work in the classroom. For these teachers, group/pair work is now popular and conducting group work in a variety of activities with unfixed group members during a formal class is one of the required competences for a qualified EFL teacher. Few would deny that the ability to conduct group work in classroom is one thing, but turning it into a really fruitful activity (based on strong comprehension, appropriate strategies and procedure set by incharge teachers) for learners is quite another. In other words, high school EFL teachers are generally encouraged to utilize group work as much as possible, especially in speaking classes, but whether or not they are fully aware of its benefits and possible problems/drawbacks as well as how to conduct it in an effective way is still open to questions because little has been known about such questions based on empirical research. Moreover, previous studies on group work such as Ababneh (2017), Ibnian (2012), John (2017), Othman and Murad (2015), Taqi and Al-Nouh (2014), and so on have largely focussed on learners' attitudes and gained inconclusive results across the board. Within Vietnam's setting, quite a number of studies have been reported concerning group work or cooperative learning and almost all of them, such as Duyen and Huan (2017), Le (2006), Luu (2010), Pham (2019), Thanh-Pham (2011), Tran and Lewis (2012), were conducted at college level only. None of them has intensively investigated EFL high school teachers' views and practice of group work in classroom. Meanwhile, Luu (2010) commented that in numerous classrooms, Vietnamese EFL teachers are changing seating arrangement to cluster learners, but not changing the way learners interact with each other as they learn. Similarly, on her survey results among Vietnamese teachers and students from different universities in Ho Chi Minh City of Vietnam, Thanh-Pham (2011) contended that "perhaps the teachers usually organized group work spontaneously with a main purpose of changing the learning atmosphere only" (p.7). More studies should, therefore, be done especially on EFL teachers' perceptions and their actual implementation during regular teaching. This calling-fordeeper investigation context has motivated the current study as being the very first done in Dong Thap province to delve into the concerned issues at high school level. To its end, the current study was aimed to answer 2 research questions: (1) What do high school EFL teachers think of group work? (2) How do they implement it in speaking classes?

\section{LITERATURE REVIEW}

What is group work? It can be defined as "students working together in a group small enough so that everyone can participate on a clearly assigned learning task" (Cohen \& Lotan, 2014). In broad terms, group work comprises any learning tasks or activities that require students to work in pairs or in groups/teams of three or more members. With regard to the procedure, the 5D model should be applied: Direct (the teacher directs students how to go about the group work), Discuss (students discuss among themselves), Develop (students develop the content for presentation), Deliver (students deliver the 
content in front of the class), and Document (the teacher documents the feedback) (John, 2017).

\section{Group work benefits in language classroom}

For its various benefits in second language learning, group work has long been supported by pedagogical arguments (Long \& Porter, 1985). Harmer (1991) believes that group work facilitates students in readily taking part in activities and reducing anxiety in order to promote language fluency in language classes. In addition, Brown (2001) confirms that group work provides a context in which individuals help each other; it is a method of helping groups as well as helping individuals; and it can enable individuals and groups to influence and change personal, group, and organizational and community problems. In the same line, Alfares (2017) states that group work benefits language learners in the learning process from cognitive, emotional and motivational aspects. Groups are helpful for students because of its independence thanks to the encouragement from learners to learners. Language learning can be promoted by group activities in the following ways (Long \& Porter, 1985): (1) Language input: Group work is one of the most valuable sources of input if it is properly handled; (2) Fluency: Students attain fluency in the use of language items already learnt; (3) Communication strategies: Students learn strategies of (i) negotiations to control input (seeking information and conformation, checking information, repetition); (ii) keeping a conversation going in speaking activities.

\section{Possible problems of group work in classroom and teacher roles}

Beebe and Masterson (2003) confirm four following drawbacks: (i) there may be pressure from the group to conform to the majority opinion. Most people do not like conflict and attempt to avoid it when possible. By readily acquiescing to the majority opinion, the individual may agree to a bad solution just to avoid conflict; (ii) an individual may dominate the discussion. This leads to members not gaining satisfaction from the group because they feel isolated in the decision making process; (iii) some members may rely too heavily on others to do the work. This is one of the most salient problems that face groups. Some members do not pitch in and do not adequately contribute to the group; (iv) it takes more time to work in a group than to work alone. It takes longer to accomplish tasks when working with others. What is more, Taqi and AlNouh (2014) consider that students did not have any improvement based on group work, and also John's study (2017) finds that the use of group work was accepted well by Class A but not by Class B in speaking skills.

As a consequence, rather than just watch and let students work by themselves during group activities, teachers (Brown, 2001) should have to monitor students' progress by moving around the classroom, pausing briefly beside each pair/group, listening to them and noting any language error or communication problems to facilitate their practice as well as help them manage disagreements. Additionally, it is useful for teachers to use a small notebook or a piece of paper on which he or she can jot down any common mistakes. Some of them can be corrected immediately but some common problems should be reminded for the whole class after finishing the activity. 
Thus, though advantageous to language classes, group work is by no means free from any problems and EFL teachers should be well aware of and get prepared to deal with them promptly and rationally by taking on multiple roles as being not only a planner, organizer, observer and evaluator but director, motivator, and supporter in case problems somehow occur. These pedagogical arguments frame theoretically the current study investigating what today's high school EFL teachers think of and actually do with group work in regular speaking classes.

\section{METHOD}

\section{Participants}

Table 1

Participants' Information

\begin{tabular}{llll}
\hline Background Information & Number (N=105) & Percentage (\%) \\
\hline Gender & Male & 31 & $29.5 \%$ \\
& Female & 74 & $70.5 \%$ \\
\hline Age & $22-29$ & 4 & $3.8 \%$ \\
(years old) & $30-39$ & 68 & $64.8 \%$ \\
& $40-49$ & 31 & $29.5 \%$ \\
& Above 50 & 2 & $1.9 \%$ \\
\hline Teaching & $5-10$ & 22 & $21.0 \%$ \\
experience (years) & $10-20$ & 69 & $65.7 \%$ \\
& Above 20 & 11 & $10.5 \%$ \\
& Less than 5 years & 3 & $2.9 \%$ \\
\hline \multirow{3}{*}{ Qualification } & B.A & 45 & $42.9 \%$ \\
& M.A & 8 & $7.7 \%$ \\
& Others (C1, B2) & 52 & $49.4 \%$ \\
\hline
\end{tabular}

As shown above, they were all high school teachers (31 males and 74 females) from more than 30 high schools in Dong Thap province, South of Vietnam. Most of them were between 30 and 49 years of age with an average of 10 years' teaching experience. Regarding academic degrees, 45 teachers hold a Bachelor of Arts (BA) (42.9\%) and 8 have got MA (7.7\%) in TESOL. Additionally, 52 out of 105 have gained B2, C1 level of English (49.4\%). Thus, the survey participants shared the first language of Vietnamese and the professional background, validating the collected data.

\section{Research instruments}

To obtain data for the target research questions, two instruments were used as follows.

(1) The questionnaire: It was designed by the current authors and was based on theoretical framework and previous studies. In the current study, the questionnaire was aimed to measure high school EFL teachers' perceptions of group work benefits, possible problems, teacher roles and implementation in speaking classes. It includes 2 main clusters of 27 items as follows (see the Appendix for details): 
Table 2

Questionnaire Items Division

\begin{tabular}{lll}
\hline & Perceptions & Questions \\
\hline Cluster 1 & Benefits & $1 \rightarrow 9$ \\
& Problems & $10 \rightarrow 15$ \\
Cluster 2 & Teachers' role & $16 \rightarrow 26$ \\
& Activities used & 27 \\
\hline
\end{tabular}

In this 5-point scale questionnaire, the participants were asked to choose their answers by marking individual items, ranging from Strongly disagree/Unimportant (1), Disagree/Moderately important (2), Unsure (3), Agree/Important (4) to Strongly agree/Very important (5). All scale values were then summed up to give overall positive scales. Therefore, it was decided that the high score on the scale would imply the favourite perception, i.e. statements would be scored 5 for "strongly agree/very important" down to 1 for "strongly disagree/unimportant".

The finished questionnaire was first reviewed by 3 colleagues (teachers of English) to assure its original validity and ease of use before piloting. From their feedback, a number of adjustments in terms of wording, item number and ordering were made. After that, the questionnaire was piloted with 23 English teachers in 2 high schools through emails within a week. The results were computed to confirm its reliability with Statistics Package for the Social Science (SPSS 20.0 for Windows). The Reliability Analysis on all the 5-point scale items showed that the reliability coefficient of the questionnaire was acceptable $(\alpha=.898)$.

\section{(2) Video-recording}

Video-recording was applied to collect the data for group work implementation in speaking classes. The teachers were randomly selected from 105 teachers who previously participated in the questionnaire and were invited for the recording.

At first, 6 teachers working full-time at different high schools ( 2 from city schools, 2 from district schools and 2 from remote areas in Dong Thap province) representing dissimilar regional and teaching environments were invited to take part in this session. In Vietnam's present context, it is still deemed a demanding job to have school teachers involved in a research project since most of them would feel somehow uncomfortable or under pressure with someone else watching their regular instructions for any reason and especially in the case of accidental observations. This also accounts for the fact that virtually all previous inquiries regarding group work/cooperative learning within the country were addressed at college level, where research projects are more ubiquitous and acceptable to faculty. Thus, prior to manipulation, the researchers contacted those teachers (both by emails and phone) and explained in detail the session purpose and that no one but the researchers would be allowed to access the obtained videos in any case. Also, their full names would be strictly kept confidential during data analysis process and in the result report afterwards. 
However, only 4 of them finally agreed to partake. One teacher was from a gifted city school (named Teacher A - male, aged 35, 10 years' teaching experience, B.A); two from one district (Teacher B - female, aged 30, 7 years' teaching experience, B.A; Teacher $\mathbf{C}$ - female, aged 45, 21 years' teaching experience, M.A) and one from a remote area (Teacher $\mathbf{D}$ - male, aged 29, 5 years' teaching experience, B.A). Upon their permissions and consent forms signed (by the teachers and students involved) for recording, 4 speaking sessions were fully video-recorded. The recording time of each session lasted 40 to 45 minutes (currently applied in Vietnam's high school system) for each unit of instruction in class. To ensure that the interaction between the teacher and students in class went on as naturally as possible, the students were not made aware of being recorded because the researchers stayed silent in the rear corner of the classroom (as non-participants) (Creswell, 2014). This instrument aimed to gain deeper insights about group work implementations by high school teachers in their regular classroom.

Right after each session ended, the teacher in charge and the researchers together sat down in a school room, watching the recorded video and sharing ideas about good points and can-improve points for approximately one hour. Then, on finishing all 4 recordings, the researchers both worked again on the recorded videos, reviewing postsession discussions with each of the 4 teachers and thereby mutually coming up with emerging themes in reference to the questionnaire results.

\section{Data collection schedule}

Data collection for the current study was conducted within 12 weeks (from January $13^{\text {th }}$, 2018 to April $8^{\text {th }}, 2018$ ) as follows:

Table 3

Data Collection Schedule

\begin{tabular}{llll}
\hline Research activities & Instruments & Outcomes & Timeline \\
\hline 1.Designing questionnaire & Questionnaire & Initial version & Week 1-2 \\
2. Piloting questionnaire & Questionnaire & Feedback from colleagues & Week 3 \\
& & Piloting results & Week 4 \\
3. Delivering and collecting questionnaire & Questionnaire & Emails collected & Week 5-6 \\
4. Collecting data by video-recording & Video-recording & Recording files & Week 5-10 \\
5. Analysing and synthesizing data & SPSS 22.0 & Final results & Week 7 - 12 \\
\hline
\end{tabular}




\section{FINDINGS}

\section{Questionnaire results}

Table 4

Teachers' Perception of Group Work Benefits

\begin{tabular}{|c|c|c|c|}
\hline No & Questionnaire items & Mean & Std. Deviation \\
\hline 1 & $\begin{array}{l}\text { Group work is an appropriate technique used in English speaking } \\
\text { classrooms }\end{array}$ & 3.9619 & .90855 \\
\hline 2 & Group work gives students more opportunities to speak English in class & 4.0095 & .99513 \\
\hline 3 & $\begin{array}{l}\text { When students work in groups, they are more active than in other } \\
\text { classroom settings }\end{array}$ & 3.7429 & .95100 \\
\hline 4 & $\begin{array}{l}\text { Students who work in groups get more than students who work } \\
\text { individually }\end{array}$ & 3.7524 & .98821 \\
\hline 5 & $\begin{array}{l}\text { Group work is an effective technique for dealing with mixed-ability } \\
\text { speaking classes }\end{array}$ & 3.7048 & .93976 \\
\hline 6 & Through group work, students can make up for lacking of language items & 3.4476 & .99982 \\
\hline 7 & $\begin{array}{l}\text { Group work creates more chances for students to discover their own } \\
\text { speaking ability }\end{array}$ & 3.9714 & .73977 \\
\hline 8 & $\begin{array}{l}\text { Group work provides more opportunities for students to increase their } \\
\text { talking time as much as possible. }\end{array}$ & 3.7048 & 96001 \\
\hline 9 & $\begin{array}{l}\text { Group work maximizes students' usage of language, reduces stress and } \\
\text { requires students to think }\end{array}$ & 3.8571 & .62678 \\
\hline
\end{tabular}

With the mean scores of all nine items between 3.4 and 4.0 (out of 5), Table 4 displays that teachers had positive perceptions about many benefits that group work brings to EFL classroom. Especially, the highest mean scores are recorded in Item 2 ( $M=4.0)$, Item $7(M=3.9)$, and Item $1(M=3.9)$ showing that they all agreed with the good impacts on students' English-speaking skills.

But in the current setting, high school class size in Vietnam is still large, ranging from 30 to 40 students of multiple English levels for each class. Furthermore, only one teacher was in charge at a time and unsuitably fixed desk arrangements are found in regular classrooms. These are unnecessarily free from unwanted problems in conducting group activities. How do the surveyed teachers think about this? The following is the answer obtained.

Table 5

Teachers' Perceptions of Possible Problems

\begin{tabular}{|c|c|c|c|}
\hline No & Questionnaire items & Mean & Std. Deviation \\
\hline 10 & $\begin{array}{l}\text { There may be ineffective communication when group members } \\
\text { seem to be misunderstanding each other }\end{array}$ & 3.3429 & 93879 \\
\hline 11 & Group work causes students' overuse of their mother tongue & 2.9619 & 1.02773 \\
\hline 12 & $\begin{array}{l}\text { It's difficult to ensure each member in group has an opportunity to } \\
\text { speak and make suggestions }\end{array}$ & 3.9810 & .65016 \\
\hline 13 & $\begin{array}{l}\text { There may be arguments between group members in negotiation } \\
\text { and compromise }\end{array}$ & 3.5905 & .91667 \\
\hline 14 & $\begin{array}{l}\text { In speaking group work, it tends to be that some students speak too } \\
\text { much while some speak very little }\end{array}$ & 4.1619 & .63736 \\
\hline 15 & $\begin{array}{l}\text { In group work, it is quite hard for teachers to notice in details what } \\
\text { is going on in each group of speaking classes }\end{array}$ & 3.1333 & 1.12717 \\
\hline
\end{tabular}

International Journal of Instruction, April $2020 \bullet$ Vol.13, No.2 
In Table 5, almost all teachers agreed that "it is hard to ensure every student in groups has a chance to communicate equally in speaking classes" (Item 12, a high mean score $\mathrm{M}=3.98$ and a low Std. $\mathrm{D}=.65$ ) and that "it tends to be that some students speak too much while some speak very little" (Item 14, a highest mean score M=4.2 and a lowest Std. $\mathrm{D}=.63$ ). "Misunderstanding each other" (Item 10), "arguments" (Item 13) and "hard to notice in details what is going on" (Item 15) are other possible problems that catch the teachers' attentions. But, fortunately "overuse of Vietnamese" (Item 11) gets the lowest score $(\mathrm{M}=2.96)$.

Since possible problems might occur in one way or another and group work will not always result in success by itself, do the teachers know what they should do in conducting group activities to support students? The answer is given as follows.

Table 6

Teachers' Perception of Their Roles in Supporting Group Work

\begin{tabular}{|c|c|c|c|}
\hline No. & Questionnaire items & Mean & Std. Dev. \\
\hline 16 & $\begin{array}{l}\text { Teachers should explain the importance of group work to the } \\
\text { students }\end{array}$ & 3.8261 & .77765 \\
\hline 17 & $\begin{array}{l}\text { Teachers should give clear instructions and explain how the group } \\
\text { work will work and will be graded }\end{array}$ & 4.3043 & .70290 \\
\hline 18 & $\begin{array}{l}\text { Teachers should use various speaking exercises to guide students } \\
\text { how to perform group work }\end{array}$ & 4.1739 & .49103 \\
\hline 19 & $\begin{array}{l}\text { Teachers should create group work tasks that get all group } \\
\text { members involved }\end{array}$ & 4.0435 & .56232 \\
\hline 20 & $\begin{array}{l}\text { Teachers should make group work relevant to the objective of the } \\
\text { speaking lesson }\end{array}$ & 4.1304 & .54808 \\
\hline 21 & $\begin{array}{l}\text { Teachers should create an activity that is suitable for the students' } \\
\text { skills and abilities }\end{array}$ & 4.1304 & .54808 \\
\hline 22 & $\begin{array}{l}\text { Teachers should structure the tasks so that each group member can } \\
\text { make an equal contribution in speaking activities }\end{array}$ & 3.9130 & .51461 \\
\hline 23 & $\begin{array}{l}\text { Teachers should set up competitions among groups to motivate the } \\
\text { group members in an appropriate speaking activity and time }\end{array}$ & 4.0000 & .60302 \\
\hline 24 & $\begin{array}{l}\text { Teachers should let students report the results of their groups to } \\
\text { the class }\end{array}$ & 4.0435 & .56232 \\
\hline 25 & $\begin{array}{l}\text { Teachers should set up some strong group work without teacher } \\
\text { assistance and encourage peer correction }\end{array}$ & 3.8261 & .65033 \\
\hline
\end{tabular}

In Table 6, all the items score around 4 (out of 5 points). All of the teachers appeared to perceive well what they should do in supporting group activities.

Additionally, Item 26 receives good suggestions for group work activities: (i) Have a good monitoring and facilitating process, make sure that all members of group work are working and design pre-speaking activity carefully so that students can get sufficient input; (ii) Provide vocabulary on each topic for students; ask students to brainstorm some key words which relate to the topic in advance; (iii) Give extra scores for the leader of the group; give marks for the whole group work activity and let students remark other groups before giving feedback; (iv) Pay more attention to weak groups to motivate group members effectively and change group members in different activities.

Meanwhile, the results from Item 27 are as follows: 
Table 7

Group Work Activities Used

\begin{tabular}{llll}
\hline No. & Activities & Response No. & $(\%)$ \\
\hline 1 & Dialogues & 61 & 12.2 \\
2 & Questions and answers exercises & 54 & 10.8 \\
3 & Brain storming & 52 & 10.4 \\
4 & Games & 68 & 13.6 \\
5 & Presentation & 41 & 8.2 \\
6 & Role play & 69 & 13.8 \\
7 & Projects & 59 & 11.8 \\
8 & Information gap & 19 & 3.8 \\
9 & Problem solving & 61 & 12.2 \\
10 & Others & 16 & 3.2 \\
& Total & 500 & 100 \\
\hline
\end{tabular}

In this case, the activities teachers most often employed in speaking classes are Role Plays (13.8\%), Games (13.6\%), Dialogues (12.2) and Problem Solving (12.2\%). But obviously, the activities implemented tend to be various rather than restricted to some specific ones.

\section{Video recording results}

As mentioned above, one teacher was from a gifted city school, Teacher A (teaching Grade 11 - Lesson 8: Our world heritage sites); two from one district, Teacher B (teaching Grade 10 - Lesson 9: Preserving the environment) and Teacher $\mathbf{C}$ (teaching Grade 10 - Lesson 8: Communication and culture); and Teacher D from a remote school (teaching Grade 10 - Lesson 9: Preserving the environment). All the four recordings were speaking lessons with 3 regular parts of pre-, while- and post-stage. The results are presented as follows with typical extracts from the recordings.

At the pre-stage, Teacher A gave 5 minutes for the students to work in pairs asking and answering 4 questions shown on the screen, while the other 3 teachers (B, C and D) only asked students to work individually.

Teacher A: I have 4 questions for the first discussion. (Showing 4 questions on the PowerPoint slides). Now in pairs, one, two, one, two... (Counting students in the line of desks). One asks and 2 answers. Who is one? Raise your hands.

Students: (Raise hands)

Teacher A: Good. You and your friends have 5 minutes to ask and answer. Now, let's start.

At the while-stage, teacher A, B and teacher D grouped students (6 - 7 members each) to make new conversations, while teacher $\mathrm{C}$ gave students some time to work individually, followed by group work.

Teacher B: You will choose a kind of pollution to talk. We will work in groups in 5 minutes. 
Students: (Turn back to the tables behind to create groups)

Additionally, Teacher B used 2 activities, pair work first and then group work. She seemed to have made her students get used to working in small groups followed by larger ones. She spent 15 minutes for the while-stage.

Teacher B:

- Find your partners? One student is Nam, one student is Lan. You will ... 5 minutes for you

- We will move to part 3, you will choose one of pollution, and this is the outline. So, how many parts are there?

- Ok. In the body there are three main points, that is reason, consequences and solution. So you will choose a kind of pollution to talk.

- Ok, 2 tables is one group. We work in group for 5 minutes. Right?

At the post-stage, all 4 teachers spent 15 minutes for students to discuss with friends and gave their presentations in front of the class. Teacher $\mathrm{C}$ allowed the students to play a game named "Find someone who", while role-playing was employed by Teacher D.

\section{DISCUSSION AND IMPLICATIONS}

As seen above from the questionnaire results (Table 4), virtually all the teachers perceived that group work is likely to provide students' opportunities to use English communicatively, discovering their own speaking ability right in the classroom as well as reducing stress and gaining more English input from other students. As a consequence, these results mostly prove that EFL teachers at high schools trusted the benefits of group work. This finding is by all means encouraging evidence because on perceiving its benefits rightly, qualified teachers will mostly try their best to actively and effectively use group activities and benefit students optimally. Few would deny that in the present context, speaking English well is a difficult task for many students in Vietnam (where English-speaking environments are virtually unavailable outside classroom and exam-driven English learning of mainly grammar and reading comprehension is still dominant in Vietnam's present high school system; perhaps this would stay the same in the near future), and it even seems to be a permanent trauma for weak students. Now group work in various formats should become a feasible measure/tool for teachers to clear off this trauma, making it a safe, meaningful, learnable, favourable and enjoyable environment when students enter English speaking lessons and reverse it to be a really pleasant experience in improving the target language skills. Although there is always a certain distance between perception and performance, the case looks quite promising given the findings obtained above and also because past research has indicated that Vietnamese students have positive responses towards classroom interaction in diverse tasks/activities of English learning (Duyen \& Huan, 2017; Le, 2006; Pham, 2019; Tran \& Lewis, 2012; etc.). As Le (2006), for instance, noted that students in two group settings (unassisted and assisted by a senior student) reported that they learned new words and group discussions helped them recall and remember English words. In the same line, Duyen and Huan concluded from their 
survey that "students knew how to communicate with one another during group work process and they tried to solve disagreements in their groups" (2017, p.13). Likewise, students' positive attitudes to group work have also been found in previous studies reported by Ababneh (2017) in Jordan, Alfares (2017) in Saudi Arabia, Masruddin (2018) in Indonesia, Meteetham (2001) in Thailand, Taqi and Al-Nouh (2014) in Kuwait, etc.

The teachers also highly shared the perceptions of possible problems occurring in group activities (Table 5). It is unquestionably ideal if all group members would take turns and speak out, expressing ideas/interests and making contributions to the common goals as repeatedly highlighted by researchers (Alfares, 2017; Brown, 2001; Harmer, 1991; Long \& Porter, 1985). Since this is hardly the case in the current conditions (due to certain external causes as mentioned above), those scores of Item 12 (It's difficult to ensure each member in group has an opportunity to speak and make suggestions) and 14 (In speaking group work, it tends to be that some students speak too much while some speak very little) top the list of possible problems. Fortunately, "overuse of Vietnamese" (the mother tongue) in group activities appeared not to worry the teachers as much as the other problems (Item $11 \mathrm{M}=2.96$, the lowest score). If this is really the case, it would be wise for teachers to step by step encourage students to use English (rather than Vietnamese) in doing group activities. Thereby, students' English speaking skills are definitely fostered to some extent, thus further harnessing possible advantages of group work in language speaking classroom.

Another pleasant finding is that the surveyed teachers were quite aware of what they should do to assist students' group activities as revealed in Table 6. They surely understood that group work for students does not mean absolutely freeing teachers from the instructional job, but instead shifting their role from the used-to-be main actors (in traditional classroom) to the planner/organizer of how group work should be carried out (Item 19, 20, 21); the director of how to lead students into group work correctly (Item $16,17)$; the supporter to ensure its good impacts on each and every group member (Item $18,22,25)$; the motivator to interest students (Item 23); and the evaluator of how the work has been done (Item 24). In addition, the suggested ideas collected from Item 26 and the results reported in Table 7 (Item 27) strongly signal that the teachers held clear perceptions of their roles in group activities as widely, repeatedly and strongly recommended in communicative language classroom (Brown, 2000; Ellis, 2005; Gillies, 2016; Harmer, 1991; Nunan, 1989, etc.) and that they should create effective activities for learners to immerse themselves in talking cooperatively instead of talking individualistically in the classrooms (Luu, 2010) as well as developing teaching activities that promote learner abilities in communicating meanings (Nunan, 2004). Therefore, the present finding appears not to be in line with what Thanh-Pham (2011) reported in her survey research among university teachers and students in Ho Chi Minh City. Rather than merely changing seating arrangement (Luu, 2010) or altering learning atmosphere (Thanh-Pham, 2011), high school teachers of English in the present study obviously made conscious efforts to utilize a variety of group activities and assumed their multiple roles for students' learning facilitated. 
The positive findings in the present study are further evidenced by the video recordings. The major good points are (i) all the four teachers properly implemented the 5D (John, 2017): Direct (the teacher directs students how to go about the group work), Discuss (students discuss among themselves), Develop (students develop the content for presentation), Deliver (students deliver the content in front of the class), and Document (the teacher documents the feedback); (ii) several activities of Role-play, Discussion, Find someone who, Questions-answers, Controlled practice, and Free practice were implemented, (iii) all students already got used to doing group work because the teachers did not spend much time for instructions or arrangements, i.e. group work is used regularly in those classes; (iv) the pre-stage was used as a lead-in to the lesson topics with short questions for whole-class, individuals or pairs; (v) group activities were found chiefly at the while-stage, lasting around 25 minutes, accounting for more than half lesson length (45 minutes each); (vi) the post-stage ended up with group presentations and teacher feedbacks; (vii) no tangible problems were recorded (Vietnamese overused, arguments, big noises, misunderstanding, lengthy duration for getting arrangements/preparations, etc. as reported in previous studies).

As a result, it is clear that EFL high school teachers perceived well the benefits of group activities in language classes and they were devotedly to bring about these benefits in their regular teachings in one way or another. This is really gratifying from the pedagogical point of view. However, based on the video observations, there is still room for improvement (as far as the present authors are concerned).

Firstly, teachers should purposefully encourage students to use English while talking, discussing in group interactions (not just when they present at the feedback time) and make this clear right from the beginning; at times reminding them when teachers move around for supervision. They all have learned daily communicative English expressions during their 4 years' lower secondary school, especially ways of expressing opinions, agreement and disagreement (such as In my opinion/I agree/disagree with that/what you said ....; Sure, yeah; I must say I find/found it so; That's just what I am/was thinking; That's just how I see it; That's reasonable. That's what I thought, too; That sounds great) (Hoang et al, 2018, p.157; Nguyen et al, 2018, p.140). These would surely help pave the way for them to actually use in need and enhance their English, undoubtedly leading to the ability to use longer, complex English sentences and further. If this is the case, then the problem of Vietnamese overuse in group activities is out of the question and should be gradually replaced purposefully by English in use to foster students' communicative competence.

Secondly, right from the start, teachers should stress the necessity of mutual work, contributions, collaboration or interdependence among group members. This is supposed to be prominently characteristic of group or socially-based activities (Gillies, 2007, 2016; Golub, 1988; Johnson \& Johnson, 2009; Lin, 2015); otherwise, there is no point conducting group work in general terms. For instance, turning back to Teacher B with the topic of pollution, it is a good topic for group work because it affects everyone at large, i.e. all should get on board and we need to collect various ideas from different people and then together weigh up and decide on the best solution(s) to the concerned 
pollution. As a result, all students should get involved to state their own opinions and suggestions. Thus, Teacher B should have not just told the students to get in groups and talk about a chosen pollution. This teacher should clearly and strongly raise the importance of group decisions based on individual participations and mutual agreements, not just from a single person, because a good discussion is one in which most students speak as much as possible (Ur, 1981). She should say something more, for example "Before you work in groups, remember that each member must say what he or she thinks about it. And then you must all together in each group decide on the best solutions and say why your group thinks so." And thus, it helps provide equal opportunities for each member and prevent the problem of "some speak too much while others speak little".

Thirdly, at feedback time teachers should exactly document students' presentation (John, 2017) by not just listening but really jot down main points from their presentations or even better write them clearly on the board so that all class can easily view; then read loudly and slowly for the entire class to pay attention, checking for confirmations within the same group and across-groups or calling for further opinions by purposely inviting weak students or those who seem to speak little in the group. Then if time is permitted, the entire class should come up with a list of solutions in order of priority based on agreements voted. Thus, virtually all are engaged and each has an opportunity to use English and develop cognitively in an English speaking environment. After that, during such a course of social interactions, in some way students will more or less sense the significance of group, class, community and individual contributions in the shared process of getting things done in human life. In that way, it will also help students gradually develop the values of interpersonal intelligence, namely the ability to understand people's thoughts, attitudes, and behaviours and thereby, to respond appropriately (Sutarman et al, 2019). This is likely to come out because Vietnamese learners are open to change (Luu, 2010) and generally appreciated teachers' instructions in group activities (Duyen \& Huan, 2017; Le, 2006; Thanh-Pham, 2011).

\section{CONCLUSION}

The current study made an attempt to probe how EFL teachers perceive group work and how they actually implement it in speaking classes at high schools in Dong Thap province, South of Vietnam. The obtained findings are gratifying because the teachers generally got positive perceptions of its benefits and possible problems. They also knew well what they should do in supporting students for success and enjoyment in group activities. The video recordings provided further confirming evidence for the related findings. All the four teachers used several pair or group activities in their instructions. However, there are points for improvement of how teachers should effectively implement group work to significantly benefit students at most in terms of language use and cognitive development.

This study is undoubtedly limited in a couple of manners due to certain constraints in Vietnam's present context as discussed earlier. First, although 105 teachers responded to the questionnaire survey, only 4 of them were involved in the recording sessions and only one 45-minute lesson for each was documented. The obtained findings, therefore, 
are hardly comprehensive because it is a common sense that groupings by most teachers are contingent on lesson contents/topics or language practice focus, and thus largely subject to altering from lesson to lesson within the same class. Secondly, teachers' philosophies/rationales for their grouping performances have not been known, which could be remedied by in-depth interviews following recording sessions, as such to provide more relevant qualitative data. As Stern (1983) asserted that "No language teacher - however strenuously he may deny his interest in theory - can teach a language without a theory of language teaching" (p.27). Thirdly, this study has yet to examine the effects of group work (in comparison with non-group work, for instance) on student learning outcome, i.e. English speaking skills in this case. As a result, it definitely calls for further studies in the field throughout the country as well as beyond, and those initial suggestions given above are hoped to merit flexible trials by high school English teachers in Dong Thap province and elsewhere.

\section{REFERENCES}

Ababneh, S. (2017). Attitudes of Jordanian students towards using group work in EFL classrooms. Advances in Language and Literary Studies, 8(1), 233-237. doi:10.7575/aiac.alls.v.8n.1p.233.

Alfares, N. (2017). Benefits and difficulties of learning in group work in EFL classes in Saudi Arabia. English Language Teaching, 10(7), 247-256. doi:10.5539/elt.v10n7p247.

Beebe, S. A., \& Masterson, J. T. (2003). Communicating in small groups. Boston, MA: Pearson.

Brown, H. D. (2000). Principles of language learning and teaching. Englewood Cliffs NJ: Prentice Hall Regents.

Brown, H. D. (2001). Teaching by principles: An interactive approach to language pedagogy. White Plains. NY: Addison Wesley Longman.

Cohen, E. G., \& Lotan, R. A. (2014). Designing group work: Strategies for the heterogeneous classroom. New York \& London: Teachers College, Columbia U.

Creswell, J. W. (2014). Research design: Qualitative, quantitative and mixed method approaches. London: Sage.

Duyen, L. T. N., \& Huan, N. B. (2017). Factors influencing group work of students in learning English as a foreign language (EFL): A case study at a Vietnamese university. Can Tho University Journal of Science, 6, 9-12.

Ellis, R. (2005). Principles of instructed language learning. System, 33, 209-24.

Gillies, R. M. (2007). Cooperative learning. Integrating theory and practice. Los Angeles: Sage Publications.

Gillies, R. M. (2016). Cooperative Learning: review of research and practice. Australian Journal of Teacher Education, 41(3), 39-54. 
Golub, J. (1988). Introduction. In J. Golub (Ed.), Focus on collaborative learning: Classroom practices in teaching English (pp. 1-2). Urbana, Illinois: National Council of Teachers of English.

Harmer, J. (1991). The practice of English language teaching. London: Longman.

Hoang, V. V., Hoang, T. H., Dao, N. L., Vu, T. L., Do, T. M., \& Nguyen, Q. T. (2018). English 11. Hanoi: Vietnam Education Publishing House.

Ibnian, K, S. (2012). Group work and attitudes of non-English major students towards learning EFL. International Journal of Humanities and Social Science, 2(4), 192-197.

John, D. (2017). Employing group work to foster speaking skills: A study of success and failure in the classroom. MEXTESOL Journal, 41(3), 1-9.

Johnson, D. W., \& Johnson, F. (2009). Joining together: Group theory and group skills. Boston: Allyn \& Bacon.

Le, P. H. H. (2006). Learning vocabulary in group work in Vietnam. RELC Journal, 37(1), 105-121.

Lin, L. (2015). Investigating Chinese, HE EFL classrooms. Berlin: Springer.

Long, M. H., \& Porter, P. A. (1985). Group work, interlanguage talk and second language acquisition. TESOL Quarterly, 19(2), 207-228.

Luu, T. T. (2010). Infusing cooperative learning into an EFL classroom. English Language Teaching, 3(2), 64-77.

Masruddin, M. (2018). The efficacy of using short video through group work in teaching speaking to Indonesian English as Foreign Language (EFL) students. Arab World English Journal, 9, (3), 282-293. https://dx.doi.org/10.24093/awej/vol9no3.19.

Meteetham, P. (2001). Case study of cooperative learning by using jigsaw technique with second-year English major students at Naresuan University (Unpublished master thesis). Mahidol Univeristy.

Nguyen, V. L., Nguyen, H. D., Dang, V. H., Dao, N. L., Than, T. L. N., \& Tran, H. P. (2017). English 8. Hanoi: Vietnam Education Publishing House.

Nunan, D. (1989). Designing tasks for the communicative classroom. Cambridge: Cambridge University Press.

Nunan, D. (2004). Task-based language teaching. Cambridge: Cambridge University.

Othman, G. H., \& Murad, H. I. (2015). A study on Kurdish students' attitudes to group work in the EFL. European Scientific Journal, 11(11), 290-303.

Pham, D. T. A. (2019). An investigation into the effects of synchronous computer mediated communication on language skills development for EFL university students in Vietnam (Unpublished doctoral dissertation). Hue University, Vietnam.

Stern, H. H. (1983). Fundamental concepts of language teaching. Oxford: Oxford U. 
Sutarman, Sunendar, D., \& Mulyati, Y. (2019). Investigating cooperative learning model based on interpersonal intelligence on language learners skill to write article. International Journal of Instruction, 12(4), 201-218. https://doi.org/10.29333/iji.2019.12413a.

Taqi, H. A., \& Al-Nouh, N. A. (2014). Effect of group work on EFL students' attitudes and learning in higher education. Journal of Education and Learning, 3(2), 52-65.

Thanh-Pham, T. H. (2011). An investigation of perceptions of Vietnamese teachers and students toward cooperative learning (CL). International Education Studies, 4(1), 3-12.

Tran, V. D., \& Lewis, R. (2012). Effects of cooperative learning on students at An Giang University in Vietnam. International Education Studies, 5(1), 86-99.

Ur, P. (1981). Discussions that work: Task-centred fluency practice. Cambridge, UK: Cambridge University Press.

\section{APPENDIX: Questionnaire}

Dear Teachers,

We are conducting a study of group work activities and would like to invite you to participate in the study. All the items include many relevant aspects of group work activities in high schools. Your careful thoughts can be important for improving pedagogical method, especially in language teaching. Please complete the questionnaire by ticking off the appropriate box that can best represent your view. Certainly, your responses will be strictly confidential and used only for research purposes.

Email address:

Section A: Background information. Please tick off $(\checkmark)$ the appropriate box $(\square)$ or provide more information in the blanks
1. Gender:
Male $\square$
Female
2. Age:
22- 29
30- 39
$40-49$
above 50

3. Total number of years of teaching English experience (including this year)
Less than 5 years
5- 10 years
$11-20$ years
more than 20 years $\square$

\section{Educational qualification}

$\begin{array}{lll}\text { Baccalaureate } \square & \text { B.A } \square & \text { M.A } \square \\ \text { Others (B2/ C1/...): } & \end{array}$

5. Which school have you been teaching in? (Optional): 
Section B: For each of the following statements, please answer by putting a tick $(\checkmark)$ in each corresponding box for SA (strongly agree), A (agree), N (neutral - Neither agree nor disagree), D (disagree), or SD (strongly disagree).
No. Questionnaire items

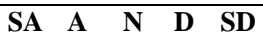

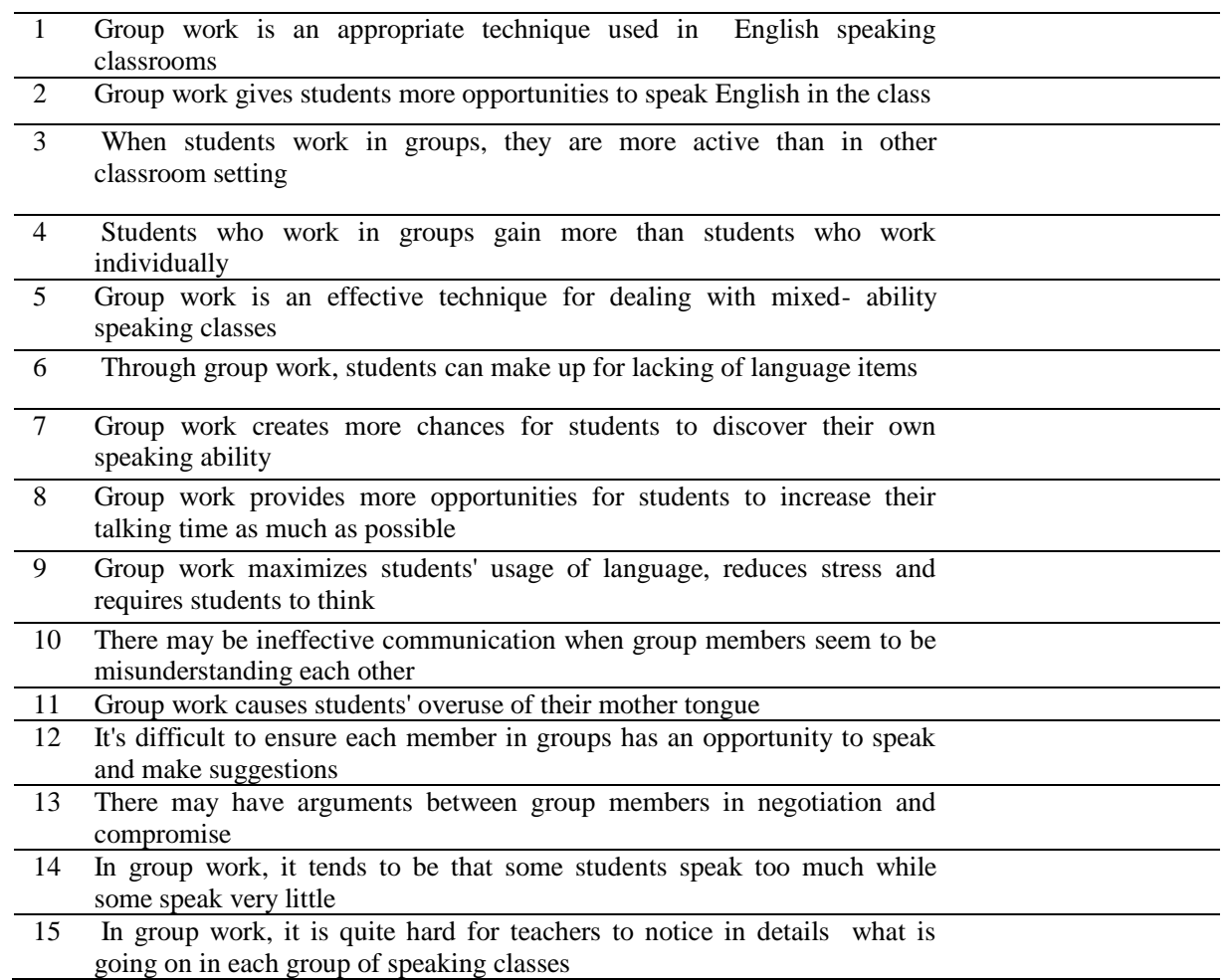

Here are a number of viewpoints teachers may consider in using Group work in their Speaking classes. Tick $\sqrt{ }$ ONE box for each to say how you feel it is.

(1= Unimportant; 2= Moderately Important; 3=Unsure; 4= Important; 5=Very Important)

\begin{tabular}{|c|c|c|c|c|c|}
\hline No. & Questionnaire items & 2 & 3 & 4 & 5 \\
\hline 16 & Teachers should explain the importance of group work to the students & & & & \\
\hline 17 & $\begin{array}{l}\text { Teachers should give clear instructions and explain how the group work will } \\
\text { work and will be graded }\end{array}$ & & & & \\
\hline 18 & $\begin{array}{l}\text { Teachers should use various speaking exercises to guide students how to } \\
\text { perform group work }\end{array}$ & & & & \\
\hline 19 & Teachers should create group work tasks that get all group members involved & & & & \\
\hline 20 & $\begin{array}{l}\text { Teachers should make the group work relevant to the objective of the } \\
\text { speaking lesson }\end{array}$ & & & & \\
\hline
\end{tabular}




\begin{tabular}{|c|c|}
\hline 21 & $\begin{array}{l}\text { Teachers should create an activity that is suitable for the students' skills and } \\
\text { abilities }\end{array}$ \\
\hline 22 & $\begin{array}{l}\text { Teachers should structure the tasks so that each group member can make an } \\
\text { equal contribution in speaking activities }\end{array}$ \\
\hline 23 & $\begin{array}{l}\text { Teachers should set up competitions among groups to motivate the group } \\
\text { members in an appropriate speaking activity and time }\end{array}$ \\
\hline 24 & Teachers should let students report the results of their groups to the class \\
\hline 25 & $\begin{array}{l}\text { Teachers should set up some strong group work without teacher assistance } \\
\text { and encourage peer correction }\end{array}$ \\
\hline 26 & Are there any other points teachers should keep in mind to make group work more effectively? Please specify. \\
\hline
\end{tabular}

27. Which type of group work activities have you used in speaking classes? Tick ONE or MORE

$\begin{array}{ll}\square \text { Dialogues } & \square \text { Questions and answers exercises } \\ \square \text { Brain Storming } & \square \text { Games } \\ \square \text { Presentation } & \square \text { Role play } \\ \square \text { Projects } & \square \text { Information Gap } \\ \square \text { Problem solving } & \square \text { Others }\end{array}$

